九州大学学術情報リポジトリ

Kyushu University Institutional Repository

A New Species of the Genus Antibothrus (Coleoptera, Bothrideridae) from Japan, with Notes on the Japanese Bothriderinae

Sasaji Hiroyuki

https://doi.org/10.5109/2611

出版情報: ESAKIA. 37, pp.111-116，1997-09-30. Entomological Laboratory，Faculty of Agriculture, Kyushu University バージョン :

権利関係 : 


\title{
A New Species of the Genus Antibothrus (Coleoptera, Bothrideridae) from Japan, with Notes on the Japanese Bothriderinae
}

\author{
Hiroyuki SASAJI
}

Biological Laboratory, Fukui University, Fukui 9 10, Japan

\begin{abstract}
A new bothriderid, Antibothrus morimotoi (Coleoptera, Cucujoidea) is described from Japan. A key to the Japanese genera of Bothriderinae is provided, with a brief description of Leptoglyphus vittntus Sharp.

Key words: Taxonomy, Coleoptera, Bothrideridae, Japan, new species.
\end{abstract}

Up to the present, 6 species of the subfamily Bothriderinae (Coleoptera: Bothrideridae) have been recognized from Japan. Recently an unknown bothriderine species was collected in Fukui Prefecture, Central Japan by Mr. Inoue, a forest entomologist. After careful examination, I concluded that it was new to science and describe it as a new species as below. In this occasion the further known species of the subfamily Bothriderinae of Japan are listed with some taxonomic notes.

Before going further, I wish to express my cordial thanks to Mr. Shigenori lnoue. the Green Center of Fukui Prefecture, Mr. Nobuyuki Narukawa, Tsu, and Mr. Teruhisa Ueno, Kyushu University, for their kind offers of the valuable materials.

\section{Antibothrus morimotoi sp. nov. \\ [Japanese name: Inoue-Hosokata]}

(Figs. 1- 3)

Body somewhat flat cylindrical, about 3.3 as long as wide, nearly parallel-sided. Uniformly reddish brown without any blackish or paler marking. Surface almost glabrous.

Head relatively large and much wider than long in dorsal aspect. eye strongly prominent laterally and grabrous. Frons relatively finely and sparsely punctate.

Antenna clearly 1 1-segmented (Fig. 2). Basal segment stout, glabrous with a sharp spine at basal side; 2nd segment much smaller than basal and strongly widened: 3rd subcylindrical, slightly longer than wide; each of 4th to 9th segments wider than long. Tenth segment strongly widening apically, about twice as wide as long: terminal (1 lth) segment transverse oval, much wider than long with a narrow stem. Detail structure of each segment are as figured.

Pronotum nearly as long as wide and hexagonal with weakly angulated sides; surface of pronotal disc roughly sculptured by large, irregullar and longitudinal depressions. Pronotal base with a pair of weak and very short elevations and depressions. 
Elytra almost parallel-sided with a short rounded apex. Three distinct longitudinal carinae present, which are almost reaching to elytral apex. Suture also carinate. Each of three intervals with a weak longitudinally carinate elevation at anterior half or anterior two-third. Surface of interstices between carinae very weakly, sparsely and roughly punctate.

Prosternal process (Fig. 3) very narrow, and weakly widening posteriory with a subtruncate apex, and nearly as long as basisternal length. Postcoxal process of prothoracic hypomeron very thin.

Protibia with a sharp terminal spine and several small but distinct denticles, with a long slender and a short spurs. Meso- and matatibia with sharp terminal spine at apex and each with two spurs.

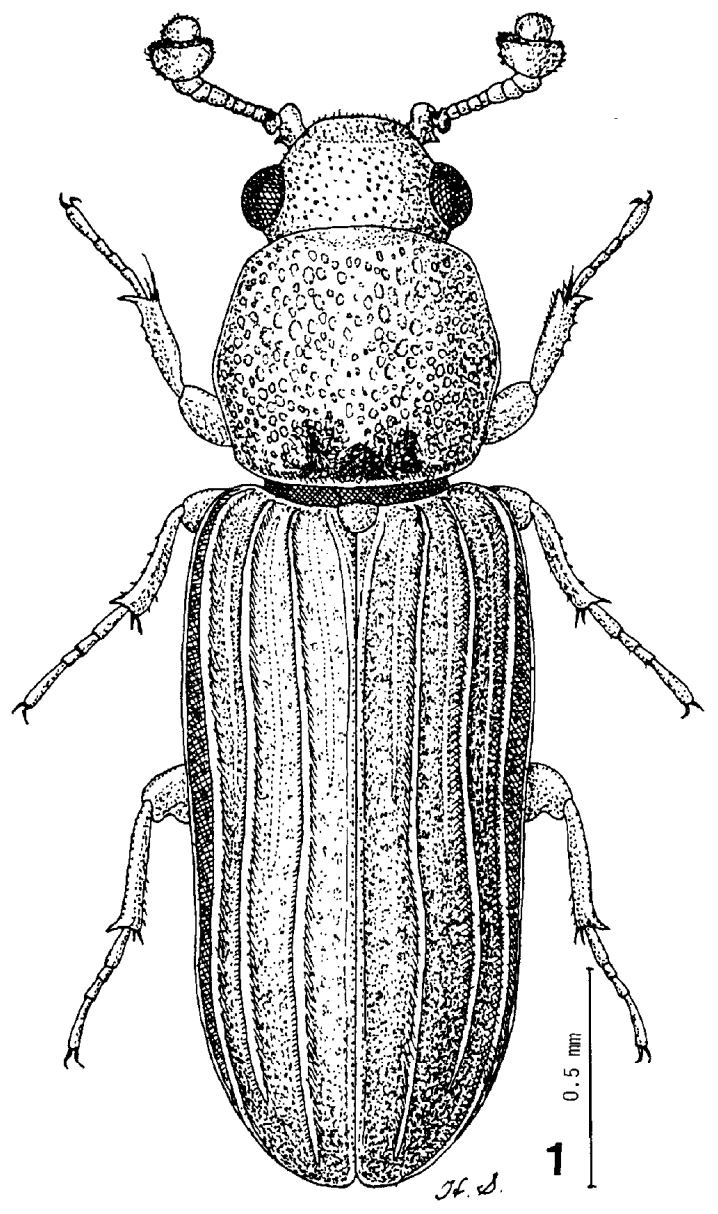

Fig. 1. Antibothrus morimotoi sp. nov. dorsal habitus. 

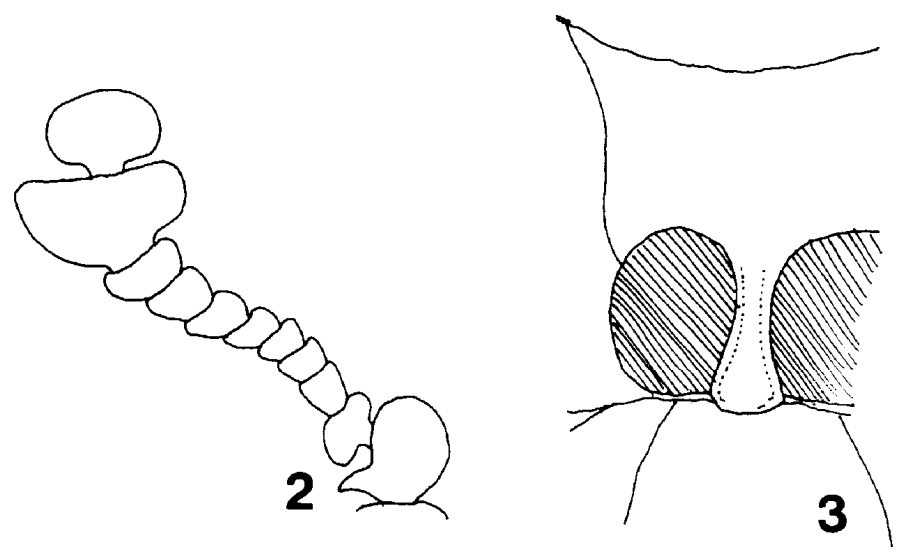

Figs. 2-3. Antibothrus morimotoi sp. nov. - 2, antenna: 3. prosternum.

Body length: 2.25-2.50 (2.50) mm; width: 0.73-0.75 (0.75) $\mathrm{mm}$, those of the holotype are in parentheces.

Distribution. Japan (Honshu).

Holotype: 1 ex. , Kami-makidani, 400m alt., Imajô-chô, Fukui Pref.. Japan, 20. vii. 1995, S. Inoue leg., preserved in the Collection of the Entomological Laboratory. Kyushu University, Fukuoka (Type No. 3056, Kyushu Univ.).

Paratypes: 2 exs., Hirakura, Mie Pref., Japan. 12-13. v. 1956, H. Ichihashi leg.. preserved in the author's collections.

Remarks. The present new species is very similar to Antibothrus fatalis Nikitsky. 1985 from Primorye, Far East Russia, but this is distinguishable from it in the following features: preapical segment of antenna much wider; basal and second antennal segments very characteristic; eye strongly prominent laterally; longitudinal furrow at pronotal median line scarcely recognized; sub-interval carinae of elytra much shorter than in $A$. fatalis; and prosternal process longer.

\section{Key to the Japanese genera of the subfamily Bothriderinae}

1. Dorsal surface set with scales. Anterior and middle coxae very widely separated.

$$
\text { .......................... Dastarcus }
$$

Dorsal surface glabrous or finely setose. Anterior and middle coxae moderately or narrowly separated by prosternal process.

2. Pronotum with 3 pairs of distinct longitudinal carinae which are interrupted by deep transverse fovea at near base. ............................... Machlotes

Pronotal surface without distinct longitudinal cariane. ...................... 3

3. Pronotum with a deep fovea on centre of disc, and elongate cordiform with a weakly arcuate sides. Antenna 11 -segmented. ................** Aeschyntelus

Pronotum with weak depressions on base of disc, and usually hexagonal in outline. 
4. Antenna 9-segmented with a large oval terminal segment which is indistinctly divided into two segments. Leptoglyphus Antenna 1 l-segmented with distinctly separated into two segments.

Antibothrus

\section{A synonymic list of the Bothriderinae of Japan}

Dastarcus helophoroides (Fairmaire, 188 1)

= Pathodermus helophoroides Fairmaire, 1881

= Dastarcus longurus Sharp, 1885

China, Japan.

Dastarcus kurosawai Sasaji, 1986

Japan (Ryukyus).

Machlotes costatus (Sharp, 1885)

= Erotylathris costatus Sharp, 1885

Japan (Hokkaido, Honshu, Tsushima), Formosa.

Aeschyntelus takeii (Nakane, 1968)

= Bothriderus takeii Nakane, 1968

= Ascetoderus takeii Nakane, 1978

Japan (Honshu).

Aeschyntelus popei (Nakane, 1978)

= Ascetoderes pope $i$ Nakane, 1978

Japan (Ogasawara Is.), China.

Leptoglyphus vittatus Sharp, 1885

Japan (Kyushu), Formosa.

Antibothrus morimotoi sp. nov.

Japan (Honshu).

\section{On Leptoglyphus vittatus Sharp, 1885}

The genus Leptoglyphus is a Bothriderus-like colydiid and is very close to the genus Arztibothrus. According to S̆lipiñski et al. (1989), 6 species are known from Japan and southeastern Asia. In this occasion, I want to illustrate and briefly describe the Japanese (and Formosan) specimens of Leptoglyphus vittatus which is the type-species of the genus.

\section{Leptoglyphus vittatus Sharp}

(Fig 4)

Elongate, subcylindrical fusiform. About 3 times as long as wide. Head distinctly longer than wide. Antenna 9-segmented with a single segmented large club; the club indistinctly divided into 2 segments. Pronotum hexagonal, nearly as long as wide: both frons and dorsum of pronotum very coarsely punctate. Elytra much wider than pronotum. sides weakly arcuate. Each elytron with 3 extremely strong longitudinal ridges throughout and a sutural groove. Each intervals almost flat and provided with 2 
rows of elongate punctures as a rule. Legs as illustrated, tibial apex sharply pointed and each 2 distinct spurs provided. Prosternal process narrow and weakly widening apically.

Body length: 2.2-3.5 mm; width: 0.6-1.2 mm.

Distribution. Japan (Kyushu), Formosa.

Specimens examined. 1 ex., Teuchi, Is. Shimokoshiki, Kagoshima Pref., Japan. 17. v. 1994, T. Ueno leg. (Ueno coll.); 1 ex., Liyuchih, Haulien Hsien, Formosa, 14 viii. 1966, H. Kamiya (H. Sasaji) leg.; 1 ex., Penpuchi, Formosa, 26. v. 1965, T. Shirôzu leg.; 1 ex., Penpuchi, Formosa, 4. vi. 1965, T. Shirôzu leg.; 2 exs., Liukuei, Formosa. 25. vii. 1970, T. Kobayashi leg., (Shibata Coll.).

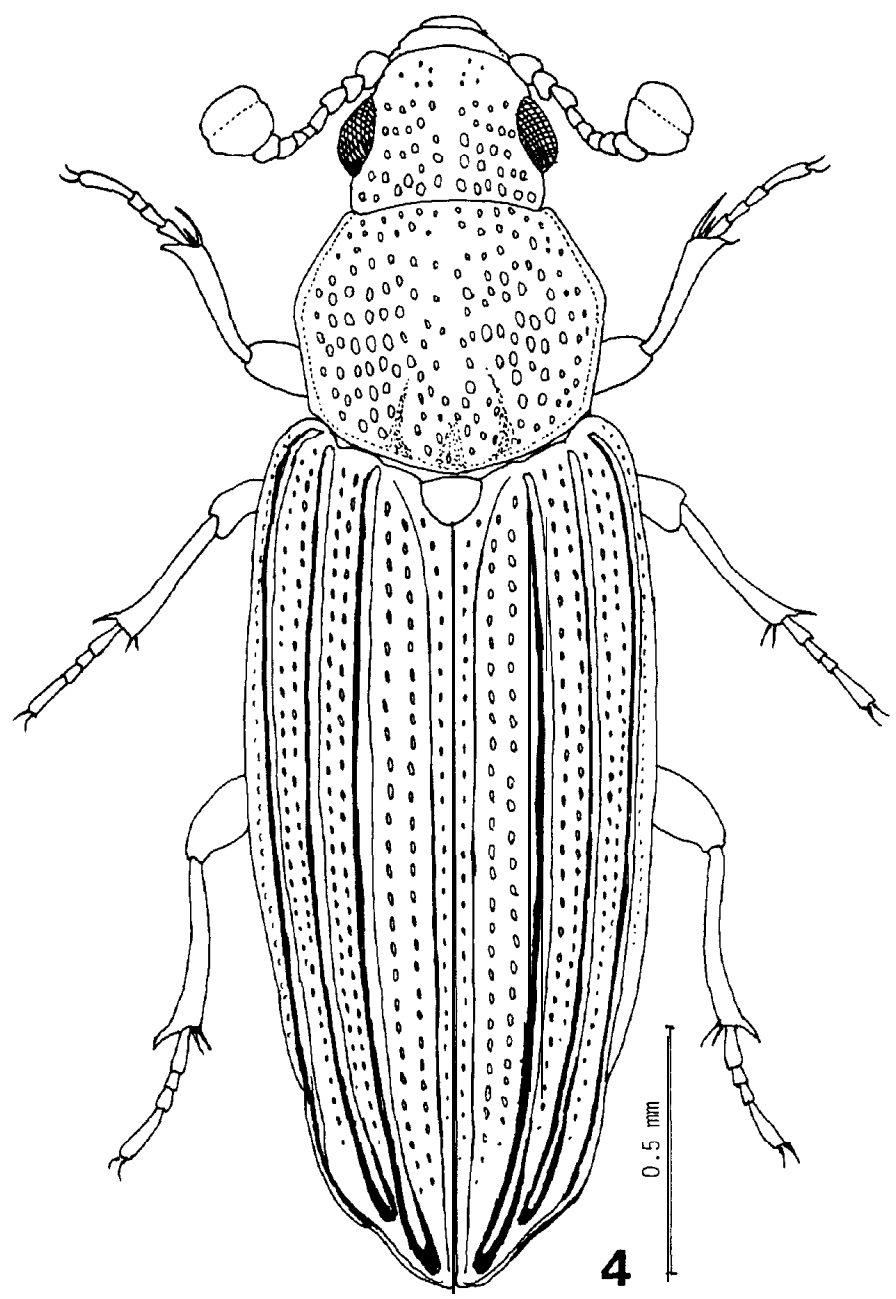

Fig. 4. Leptoglyphus vittatus Sharp, dorsal habitus. 


\section{References}

Dajoz, R., 1977. Coléoptères Colydiidae et Anommatidae Palearctiques. In"Faune de l'Europe et du Bassin Méditeitteranéen", 8, Paris. 280 pp.

Fairmaire, L. , 1881. Descriptions de quelques Coléoptères de Syrie. Annls. Soc. Entom. France, (6) 1: 79-88.

Grouvelle, A., 1913. A. H. Sauter's Formosa-Ausbeute. Rhysodidae. Nitidulidae. Ostomidae, Colydiidae, Passandriidae, Cucujidae, Cryptophagidae, Diphyllidae. Lathrididiidae, Mycetophagidae, Dermastidae. Arckiv fiir Naturg., 79 (Abt. A. H. 11, 1914): 33-76.

Nakane, T., 1968. New or little-known Coleoptera from Japan and its adjacent regions. XXVI. Cucujoidea. Fragm. Coleopt., 19: 75-76.

Nakane, T., 1978. On some interesting species of Coleoptera from Izu and Ogasawara Islands, with descriptions of new species. Mem. nut. Sci. Mus.Tokyo, 11:155161.

Nikitsky, N. B., 1985. A new species of the genus Antibotkrus (Coleoptera, Colydiidae) from the South of the Soviet Far East. Zool. Zkurn., 64: 625-628. (In Russian)

Sasaji, H., 1985. Colydiidae. In Kurosawa, Y. et al., "The Coleoptera of Japan in Color. III", pp. 291-295, pl. 48. (In Japanese)

Sasaji, H., 1986. Notes on the Colydiidae (Coleoptera) of Japan and Formosa. Ent. Papers pres. Y. Kurosawa. Coleopterists' Association, Tokyo: 243-249.

Sharp, D., 1885. On the Colydiidae collected by Mr. G. Lewis in Japan. J. Linn. Soc. London, 19: 58-84, pl. 3.

Slipiiiski, S. A., R. R. Pope and R. J. W. Adridge. 1989. A review of the world Bothriderini (Coleoptera, Bothrideridae) . Bull. entom. Pologne, 59: 13 1-202. 